\title{
Untreated Extensive Stage Small Cell Lung
} \section{Carcinoma}

National Cancer Institute

\section{Source}

National Cancer Institute. Untreated Extensive Stage Small Cell Lung Carcinoma. NCI

Thesaurus. Code C129947.

A finding of small cell carcinoma which has spread beyond one hemi-thorax and the regional lymph nodes and has not been treated. 